Post operative conditions were dissatisfactory in 9 cases of these $24: 3$ of them had intramedullary tumors and 6 had intradural extramedullary tumors.

Generally, patients with bad postoperative condition had a longer duration of suffering and severer clinical condition while being admitted than those with good ones.

As far as we have observed, an early diagnosis and early operation are necessary for tumors of the spinal cord, and a long-suffered patient showing progressed spinal symptoms at the time of admittance is considered to be treated just as one with malignant tumor, eventhough it is the benign tumor of spinal cord.

\title{
96. Surgical Treatment of Syringomyelia and Hydromyelia
}

\author{
Hitoo YAMANE \\ Department of Orthopedic Surgery, School of Medicine, Keio University
}

In 1892, Abbe and Coley inclsed a cystic swelling in the spinal cord with subsequent improvement. The procedure is usually referred to as 'Elsberg-Poussepp operatiou'.

Five cases were experienced in the period beginning from 1949 to April, 1965 which revealed cystic condition or cavity formation in the spinal cord in the series of department of orthopedics, Keio University Medical School. All cases were treated surgically.

1) Case

Details of each case are summerised in the Table 1.

2) Operative technique

In the operation the following points are stressed.

a) The puncture is performed using a $1 / 4 \mathrm{~mm}$ needle at the site of maximum swelling of the spinal cord. After having confirmed the content and the exact location of the lesion, myelotomy is performed longitudinally slightly deviating from the midline.

b) No foreign materials are left in the cavity for the purpose of drainage.

c) As a rule, dura mater is sutured so far as the expansion of the cord is not remarkable, however, a piece of fascia is used for the coverage of dural defect, if necessary.

3) Evaluation of late results 
Three out of five cases described here showed improvement. Postoperative results of fifty-five cases, including our five cases, have been reviewed in which 70 per cent showed improvement.

4) Snmmary

Five cases of syringomyelia and hydromyelia are presented. Myelotomy was carried out in each case which proved to be effective. The author believes that the possible remission is expected by myelotomy following laminectomy in syringomylia.

Table I. Summary of Details of Personal Cases

\begin{tabular}{|c|c|c|c|c|c|}
\hline $\begin{array}{l}\text { Case } \\
\text { No. }\end{array}$ & $\begin{array}{l}\text { Sex and } \\
\text { Age at Op. }\end{array}$ & Motor Symtoms & $\begin{array}{l}\text { Sensory } \\
\text { Symptoms }\end{array}$ & $\begin{array}{l}\text { Follow } \\
\text { Up. Years }\end{array}$ & Late Results \\
\hline 1 & M. 38 & $\begin{array}{l}\text { Paresis both } \\
\text { hands. }\end{array}$ & $\begin{array}{l}\text { Impaired pain } \\
\text { and touch in } \\
\text { ulnar side in } \\
\text { hand }\end{array}$ & 5.8 & $\begin{array}{l}\text { Sensory improve- } \\
\text { ment of hands, } \\
\text { returned to work }\end{array}$ \\
\hline 2 & M. 29 & $\begin{array}{l}\text { Paresis right } \\
\text { arm, hand } \\
\text { and leg. }\end{array}$ & $\begin{array}{l}\text { Impaired pain } \\
\text { and touch } \\
\text { C } 4-T 6\end{array}$ & 0.5 & $\begin{array}{l}\text { Improved followed } \\
\text { by deterioration }\end{array}$ \\
\hline 3 & M. 7 & $\begin{array}{l}\text { Quadriplegia } \\
\text { left worse }\end{array}$ & $\begin{array}{l}\text { All forms } \\
\text { impaired C } 6 \\
\text { down }\end{array}$ & 0.3 & $\begin{array}{l}\text { Died } 3 \text { months after } \\
\text { Ope. from acute } \\
\text { yellow liver atrophy }\end{array}$ \\
\hline 4 & F. 49 & $\begin{array}{l}\text { Disturbance } \\
\text { in gait }\end{array}$ & $\begin{array}{l}\text { Slight impair- } \\
\text { ment pain and } \\
\text { touch } C 4-6 \\
\text { and } L 1-5\end{array}$ & 1.5 & $\begin{array}{l}\text { Initial improvent } \\
\text { followed by deterio- } \\
\text { ration and later a } \\
\text { remission }\end{array}$ \\
\hline 5 & M. 54 & $\begin{array}{l}\text { Spastic para } \\
\text { plegia, legs }\end{array}$ & $\begin{array}{l}\text { All forms } \\
\text { impaired } T 2 \\
\text { down }\end{array}$ & 0.3 & No change \\
\hline
\end{tabular}

\title{
97. Studies of the Brain on Scoliosis
}

\author{
Jiro Suzuk I, Shun-ichi Inoue, Haruo Tsuj, \\ and Minoru Mitsuhashi \\ Department of Orthopedic Surgery, University of Chiba School of Medicine \\ Yutaka MAKINo and Akira WAKANA \\ Department of Neuropsychiatry, University of Chiba School of Medicine
}

Scoliosis has been studied on several pathognomonic items, but there are still many unknown problems. Recently, we studied on the brain chiefly 